\title{
The Effect of International Migration on Unemployment: An Empirical Analysis on the European Countries
}

\author{
Bekir GÜNDOĞMUȘ ${ }^{1} \&$ Musa BAYIR ${ }^{2}$
}

\begin{abstract}
Europe attracts attention in terms of geography where immigrant movements are intense. The region received international migrant heavily because of World War II, the fall of the Berlin Wall, and its connections with Africa and Latin America. After the 2000s, the war, civil conflict and political instability in especially Afghanistan, the Middle East and Africa increased the migration movements. Migration movements have important social and political consequences as well as economic consequences. The most essential of these is the fluctuations in the labour market. The study aims to empirically investigate the effect of international migration on unemployment rates in European countries. Panel regression analysis is preferred as a method. The analysis performed for 27 European countries and between 2000-2017 years. Empirical analysis results show that international migration does not have a statistically significant effect on unemployment. In addition, increases in GDP, public expenditures, education expenditures and wage rises reduce unemployment rates.
\end{abstract}

Key Words: Europe, Unemployment, International migration, Immigrants, GDP, Panel regression analysis

\section{Uluslararası Göçün İşsizlik Üzerindeki Etkisi: Avrupa Ülkelerine Yönelik Ampirik Bir} Analiz

\section{Özet}

Avrupa göçmen hareketlerinin yoğun olduğu bir coğrafya olarak dikkat çekmektedir. II. Dünya Savaşı, Berlin Duvarının yıkılışı, Afrika ve Latin Amerika ile olan bağlantıları nedeniyle bölge yoğun bir şekilde göç almıştır. 2000’li yıllardan sonra, özellikle Afganistan, Ortadoğu ve Afrika'da yaşanan savaş, iç çatışma ve politik istikrarsızlıklar göç hareketlerini daha da artırmışır. Göç hareketlerinin sosyal ve siyasi neticeleri olduğu kadar önemli ekonomik sonuçları da bulunmaktadır. Bunların başında işgücü piyasalarında oluşturduğu dalgalanmalar gelmektedir. Çalısma Avrupa ülkelerinde uluslararası göçün işsizlik oranları üzerindeki etkisini ampirik olarak araştırmayı amaçlamaktadır. Yöntem olarak panel regresyon analizi tercih edilmektedir. Analizler 27 Avrupa ülkesi için 2000-2017 yılları arasında gerçekleştirilmiştir. Ampirik analiz sonuçları uluslararası göçün işsizlik üzerinde istatistiksel açıdan anlamlı bir etkisinin bulunmadığını göstermektedir. Ek olarak, GSYiH, kamu harcamaları, eğitim harcamaları ve ücretlerdeki artış işsizlik oranlarını düşürmektedir.

Anahtar Kelimeler: Avrupa, İşsizlik, Uluslararası göç, Göçmenler, GSYİH, Panel regresyon analizi

\section{Atıf İçin / Please Cite As:}

Gündoğmuş, B., \& Bayır, M. (2021). The effect of international migration on unemployment: an empirical analysis on the European countries. Manas Sosyal Arastırmalar Dergisi, 10(4), 2204-2217.

Geliş Tarihi / Received Date: 20.01.2021

Kabul Tarihi / Accepted Date: 11.05.2021

\footnotetext{
${ }^{1}$ Dr. Öğr. Üyesi - Bandırma Onyedi Eylül Üniversitesi İktisadi ve İdari Bilimler Fakültesi, gundogmusbkr@gmail.com ORCID: 0000-0002-4279-5935

2 Dr. Öğr. Üyesi - Bandırma Onyedi Eylül Üniversitesi İktisadi ve İdari Bilimler Fakültesi, musa.bayir@gmail.com

(D) ORCID: 0000-0002-6877-4032
} 


\section{Introduction}

The phenomenon of migration has an important quality that left its mark on the 20th and 21st centuries. It has become an inevitable responsibility and obligation for social scientists to discuss why and how migration took place and to reveal the relationship dimension of migration with other variables in this period, which is described as the "age of migration" in the words of Castles \& Miller (1993). As a matter of fact, aside from the fact that migration continues to be updated in the context of economic and political developments; there is the globalization of migration in terms of affecting relatively more countries, acceleration of migration due to the increase in international migration mobility, differentiation of migration due to the relative complexity of immigration and immigrant patterns, feminization of migration compared to the early periods, and the increasing politicization of migration due to intergovernmental relations and increasing security policies (Castles et al., 2008, p. 12-14). These dimensions of the phenomenon of migration are also reflected in numerical data. According to the data of the International Organization for Migration (IOM), the number of international migrants, which was approximately 85 million in 1970, reached 250 million, corresponding to $3.5 \%$ of the world population by the end of 2019, while the estimates for 2020 are around 275 million (IOM, 2020). The rise of immigration to this extent undoubtedly increases its area of influence.

At this point, it becomes necessary to ask the question "why do people migrate?". It is clear that the motivation of people to supply their needs lies at the basis of the phenomenon of migration. The types of needs that can be diversified starting from the lowest level of the needs hierarchy theorized by A. Maslow (1943, p. 370-396)) on the "A Theory of Human Motivation" essay, can cause migration mobility in all directions. While some people move from one place to another for the purpose of accessing food or water resources or providing security, others may migrate for the purpose of education, health or more status. This relationship between the phenomenon of migration and need is also focused on mutual interaction. Because it is possible that migration triggers new needs and these new needs may cause new migrations. In this case, it is necessary to draw attention to the position of the phenomenon of migration not only affecting but also being affected. As a matter of fact, it is expected that political, social, environmental and cultural factors come into play together with the needs of people in understanding the reasons or consequences of migration mobility.

So, how should we evaluate the level of the relationship between migration and labour markets as of 2020 ? Is there any change compared to previous periods? The study, which searches for answers to these and similar questions, will also provide an opportunity to analyse the truthfulness of the approach of "making migrants pay the bill for economic crises", which develops in parallel with the fact that migrants, who are often seen as "potential suspects" in the receiving country, are the weakest link in the labour market. In this context, empirical research is performed between 2000-2017 by using official statistical data. It is aimed to determine the effect of migration on unemployment rates with empirical estimates. As a matter of fact, when the literature is reviewed, there is a considerable amount of research with different results on the issue is reached. The factor that makes this research original is to obtain results regarding a relatively recent period by using data regarding a period of intense immigration from the Middle East and West Asia for various reasons. In this context, firstly, the theoretical framework of the relationship between migration and labour markets will be explained by using economically based theories that describe international migration, and an empirical literature review will be made on the relationship between international migration and unemployment. Then, an empirical analysis will be performed using panel regression method by the 27 European countries data. Finally, the empirical results will be emphasized and interpreted.

\section{Theoretical Background}

Emigration phenomenon, which emphasizes spatial mobility in essence, refers to a long process with its wide scope. As a matter of fact, the arrival of individuals or groups moving from point A to point B for any reason does not end the process; on the contrary, it triggers continuous changes and transformations in social, political and economic fields. This reality is at the source of the continuous updating of the theoretical framework to explain this long-term process. This can be clearly seen when the course of international migration discussed in the study is followed in the 20th and 21st centuries. While the main motivation of the intense international migration mobility observed especially after the Second World War was the labour markets, it is seen that in the 2000s, internal conflict, occupation and wars caused 
immigration, therefore security-centered theoretical approaches (Heywood, 2013, p. 215) were brought to the agenda. Since the subject of the study focuses on the relationship between migration and labour markets, the theoretical framework that should be focused is focused on the economic approach. Among the economic theories that stand out in this sense; neoclassical macro / micro theory, new economy of migration, push-pull theory, cumulative causality, world systems theory, institutional theory and dual labour market theory.

The early theories of international migration in the literature were formed on the basis of the assumption that migration can be explained with certain judgments such as the laws of physics, although they were abandoned later. Referring to the certainty of demographic mobility as the main basis for this, Ravenstein's report titled "Immigration Laws" has long been generally accepted on the grounds that it determines the framework of international migration. The theory, which was created with the acceptance of the determinacy of the economy, is based on various assumptions such as that migration is generally preferred by those living in rural areas, it is made for short distances, and it is directed towards trade and industrial centers in long distances. Therefore, people are assumed to migrate with economic motives as a result of their rational choices (Ravenstein, 1885, p. 198-199). However, more specific economic approaches to explain international migration have emerged, as this approach is inadequate to answer the question "if all people are immigrants by nature, why some are immigrants and others are not" (Petersen, 1958, p. 258). As can be seen in the table, many theories of international migration classified by Bijak (2006) have been developed.

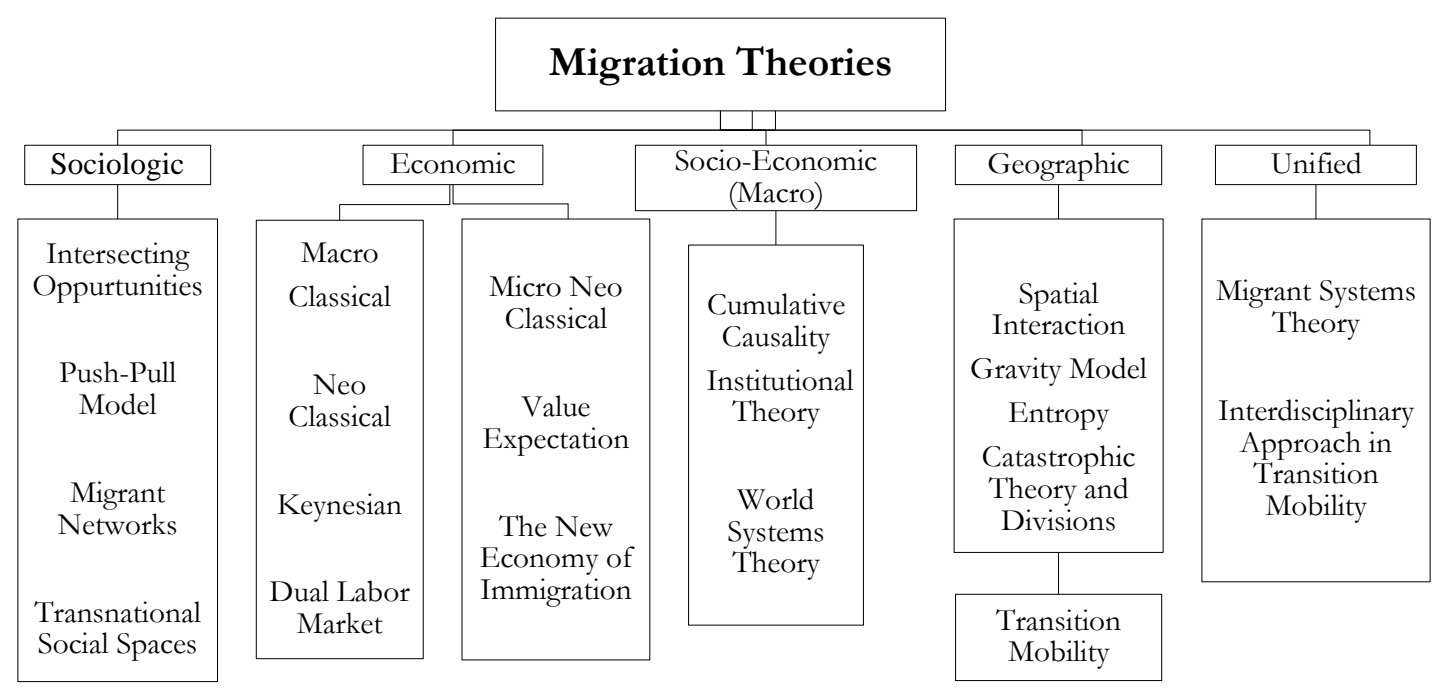

Figure 1. Immigration Theories Scheme (Bijak, 2006, p. 5)

Economically based migration theories initially focus on employers' labour need and the motivation of workers to raise welfare / gain. Thus, the relationship between migration and labour markets is tried to be understood. For example, the "Push-Pull" theory put forward by E. Lee tries to explain the migration by putting forward the driving factors of the source country and the attractive sides of the target country (Lee, 1966, p. 50). According to this theory, which can also be considered as an update of Ravenstein's assumptions, the immigration decision cannot be rational for everyone, even it may be obligatory for some. Developments that directly affect the life order such as acting with family decision, death or divorce, retirement are among the examples that can directly affect the decision process of individuals (Lee, 1966, p. 51-52).

"Neoclassical Micro and Macro" theories, also known as equilibrium theory, assume that the imbalances and wage differences in the labour markets in the receiving and sending countries are balanced with migration mobility. According to the theory developed by Lewis (1954), countries that have a labour supply but have capital problems, while low wage policy is applied, rich countries with a capital supply but not sufficient labour supply have high wages. Due to this imbalance caused by the wage difference, lowwage workers tend to migrate to high-wage countries. As a result of migration, the labour supply decreases in the poor country and starts to increase in the rich country. Likewise, while wage rates increase in the poor country, they are balanced in the rich country (Robinson, 2005, p. 5). In addition to this assumption of neoclassical macro theory, particular emphasis is placed on the preference of the individual in micro 
theory. This model developed by Sjaastad, Borjas and Todaro suggests that individuals make cost / profit calculations by referring to rational choice and make the decision to migrate voluntarily with the hope of obtaining relatively high income (Güllüpınar, 2012, p. 60).

Despite the neoclassical approach that prioritizes the rational thought of the individual, with the theory of "The New Economy of Immigration", the idea that not only the individual but also the household decision is effective in the decision of immigration has emerged. According to the theory, which refers to the collective decision-making process, collective decision making is preferred as not only the individual but also the household is affected by the migration action. As a matter of fact, the decision to be made is not only determined by the motivation of income increase, security-poverty etc. It also aims to eliminate concerns (Stark, \& Bloom, 1985, p. 173-178). While the risks related to household income in developed countries are tried to be compensated by legal regulations such as unemployment insurance and product insurance, in underdeveloped countries, individuals as well as households are struggling with possible problems in the market by acting together, since these opportunities are mostly deprived. Household members follow various strategies in response to economic crises. Some find a job in the local economy, while others find the opportunity to work abroad in another city of the same country. When the economic balance is disturbed, the household income is tried to be balanced with the income of the individuals who migrated (Abadan-Unat, 2017, p. 56). The New Economy of Immigration theory suggests that international migration movement cannot be prevented by ending wage differentials in labour markets. Accordingly, while taking measures to regulate the labour market in order to combat migration, social and economic supports should also be emphasized. It is thought that improvements such as the regulation of unemployment insurance, retirement and bonus systems will decrease the poverty of households relatively, while also decreasing their migration motivation (Gündoğmuş, 2018, p. 25).

Contrary to these theoretical approaches that prioritize individual and household decisions, the "World Systems Theory", which prioritizes macro developments and is based on the critique of capitalism, has brought a new perspective to understand international migration. This theory, which has a historicalstructuralist character, draws attention to the unequal distribution of economic and political power in the world economy on the basis of Marxist political economy. The theory, which emphasizes the structure of the current world-system that enriches the rich and supports unequal development and exploitation of poor country resources, suggests that migration is seen as a cheap labour movement. In fact, immigration has as much effect as military domination in terms of the third world being dependent on the first world and controlling world trade and interests (Castles, \& Miller, 2008, p. 34-35). The world-systems theory, which is revealed by the centre-periphery divergence, draws attention to the fact that industrial companies in the capitalist core countries set up assembly-based factories in developing peripheral countries, thus making production in those countries export-oriented. The reflection of factory work, which has been substituted for traditional production mechanisms, on the labour market develops as the male labour force's orientation towards job search due to the priority given to female labour. Therefore, immigrant supply arises in the surrounding regions due to capitalist economies. The cities in the central countries where immigrants are headed are becoming "global cities", thus creating a labour market for unskilled jobs to be performed by migrant workers.

The theory of the "Divided Labour Market", developed by Piore (1986) regarding the relationship between labour markets and migration mobility, is based on the claim developed by Neoclassical theories with a much more comprehensive framework. According to Piore (1986), who argues that wage differences are not a necessary and / or sufficient condition of labour migration, migration mobility must be continuous due to the nature of the labour market. In other words, labour supply is not in a structure that will reach sufficient saturation after a while, for example when wage differences disappear. On the contrary, immigrants have taken their place as important actors in the economies of developed countries. Because the labor market has a distinction between work to be done by migrant workers and work to be done by domestic workers. Jobs that can be expressed as primary sectors are stable and qualified, while jobs in the secondary sector are unstable and unskilled. While local workers are turning to more attractive professions than their current situation, migrants fill their vacancies. Because migrant workers who do not have too many expectations about professional and social status seek labour-intensive jobs. The " $3 \mathrm{D}$ (dirty- dangerous-difficult)" scale (Piore, 1986, p. 24), which is used to describe labour-intensive jobs, offers enough insight into the subject. As long as these labour-intensive jobs exist, the demand for migrant labour will continue to exist. To be more precise, migration movements are not due to factors 
such as high unemployment and/or low wages of the source country, but from the low-wage labour force need of the target country.

So why do some countries need consistently cheap and flexible labour? Piore talks about four main factors. The first of these; it is structural inflammation. As the wage increase of the unskilled worker at the lowest level means a wage increase up to the top hierarchically, the solution is to import labour force willing to low wages. As a matter of fact, the difference between capital and labour becomes important here. While capital, which is the constant factor of production, can always survive, labour is considered as a variable factor as the payroll shrinks in case of a decrease in demand. This can be thought of as the need for sacrificial labour. Second other factor; it is the capacity to meet the demand for status. The existence of unskilled and low-wage jobs facilitates the transition of people to the next level. Domestic workers who want to obtain status can move to prestigious professions in the context of vertical mobility thanks to migrant workers. Third factor; it is the continuous, unlimited supply of labour. Respectively from the historical process of the United States from Europe, Mexico, Latin America and the Caribbean to meet the labour supply, Turkey and Germany before a request from Yugoslavia after labour from Eastern Europe are examples accordingly. The fourth feature is the continuity of the migration flow. Today, despite the fact that almost impenetrable legal walls were built with Europe Castle practices, or despite the USA's building of thick walls of kilometres long on the Mexican border, immigration continues in a way. It is not normally understandable that hundreds of thousands of Syrians, who easily risk death, set out on a European journey through the Mediterranean. However, this is also a case (Cited in: Piore. AbadanUnat, 2017, p. 58-59).

In terms of showing the dependency relationship between migration and labour markets, it is also necessary to mention the "Cumulative Causality" theory, which is among the current approaches. According to the theory, each migration stream changes the social framework in which the subsequent decision to emigrate is made. With the establishment / expansion of transnational areas and the development of organizations that support migration, international migration continues and renews itself in other ways in addition to the mobility expected to increase over time. This situation is explained with the concept of "cumulative causality". For example, the settling of immigrants in a country and their concentration in certain sectors causes this type of job to be labelled as "immigrant work". As such, this type of job is no longer preferred and even underestimated by domestic workers in the labour market. Therefore, labour demand constantly arises in order to maintain that job, thus the relationship between migration and the labour market becomes permanent (Massey et al., 2014, p. 30-33). The fact that the automotive industry is labelled as an immigrant business in Europe and as a domestic business in the USA can be shown as an example of this.

One of the current theoretical approaches created after the experiences in international migration processes is the "Institutional Theory" approach (Meyer, \& Rowan, 1977, p. 340-363). Accordingly, with the start of the migration process, institutional structures and voluntary organizations that support migration mobility also emerge with migrants. Through these structures, continuity of immigration mobility is provided. This situation actually includes a certain degree of necessity. The vast majority of people who turn to countries with labor demand are insufficient to meet legal requirements such as visa, work permit, and residence permit. For this, intermediary institutions are needed. Some of these organizations, some of which provide services such as professional counselling and guidance through legal means, without making a profit, work illegally (human trafficking, etc.) (Bijak, 2006, p. 7). While these emerging intermediary organizations are described as "immigration industry", it is stated that a significant part of these intermediate structures have a colonial character, especially in case of illegal immigration or potential immigrant excess (Castles, \& Miller, 2008, p. 39). According to Abadan-Unat (2017), the increase in the number of transnational migrants institutionalizes the international migration flow relatively more. This situation has a negative effect on governments' control of immigration flows. Controls by the police force increase the number of black traders who make high profits from asylum seekers, and the tightened migration policies are interrupted by the resistance of human rights defenders.

The theoretical framework that can be summarized in this way shows that the relationship between migration and labour markets is interaction-oriented. However, the level of the relationship does not conclude that migration clearly constricts or increases labour markets. On the contrary, as stated in the dual labour market theory, migrant workers actually do the job allocated to them in the labour market as they concentrate on unskilled jobs that local workers do not like or prefer. The negative effect of the 
unemployment level of the emigrant country, as pointed out by the neoclassical theory, contains a separate issue.

\section{Empirical Literature}

It can be stated that international migration has become a very important subject for European economies after World War II and especially after the fall of the Berlin Wall. However, globalization draws attention as an important phenomenon that increases international human mobility. In this respect, there are many empirical studies investigating the impact of international migration on economic indicators in developed countries such as the USA, Australia and Canada, except for European countries. In addition, as there are papers that analyse only one country, there are also some studies that take into account country groups.

Firstly, we evaluate studies that analyse non-European countries and only one country. Ozcan (2020) investigates the relationship between international migration and various economic variables between 1990 and 2016, in the 15 regions of the USA that received the most immigration. Analysis results show that immigration increased unemployment in the seven most populous states, while it did not significantly affect unemployment in the other eight states. Breunig et al. (2017) analysed the impact of international migration on the employment market for the Australian economy over the period 2003-2012. In the study, there is no evidence that international migration is effective in the employment of indigene in Australia's labour market. In the first of the studies investigating the impact of international migration on the labour markets in the Canadian economy, Islam (2007) analysed the period 1961-2002. The causality tests show that there is no relationship between migration and unemployment. Similarly, the cointegration test indicates that there is no increase in total unemployment due to migration in the long run. Latif (2015) determined the analysis period as 1983-2010 and reached different estimation results. According to results, immigration has a positive effect on unemployment rates in the short term and there is a causality relationship from migration to unemployment rates. Cohen-Goldner and Paserman (2004) examines the effect of mass immigration to Israel after the collapse of the Soviet Union on the local labour market. The analysis period of the study covers the period 1989-1999. Analysis results show that neither in the short term nor in the long-term, migration has any effect on employment.

In the literature, some studies have analysed the relationship between international migration and unemployment in the OECD and European countries and, they used panel data method. Longhi et al. (2006) analysed the impact of international migration on employment of local workers. As an average of the different estimates made, it is concluded that a $1 \%$ increase in the number of migrants has a negative effect of $0.024 \%$ on the employment of local workers. In addition, it is stated that the effect is more prominent in Europe than in the USA. Jean and Jiménez (2011) investigate the impact of international migration on unemployment rates. The analysis includes the period 1984-2003. It is stated that immigration has a temporary effect on unemployment, although there is no significant long-term effect. Docquier et al. (2016) examine the impact of international migration on labour markets in OECD countries during the 1990s. Analysis results show that migration has a positive or no effect on local employment. Damette and Fromentin (2013) analysed the impact of migration on local labour markets. Analysis results indicate that the increase in the number of immigrants has a negative effect in the short term in only Anglo-Saxon countries. Boubtane et al. (2013) performed an analysis for the period 19872009. According to the results, international migration has a negative effect on unemployment rates. However, it is stated that unemployment rates in the receiving country have an also negative effect on migration. In other words, the increase in unemployment rates in these countries decreases international migration. Ortega and Peri (2009) investigated the impact of international migration on employment rates in OECD and 74 other countries during 1980-2005. Analysis results reveal that while international migration has a positive effect on the overall employment rates, it has not any effect on the employment of indigenous citizens. Apart from these studies, Longhi et al. (2010) performed an analysis for investigating the impact of international immigration on employment in Europe, the USA and Israel. The study shows that the impact of international migration on employment is not considerable.

In the literature, there are studies investigating the effect of international migration on labour markets in only European countries with panel data analysis. Angrist and Kugler (2001) show that international migration had a very small negative impact on unemployment in 18 European countries in the period of 1983-1999. Ortiz et al. (2015) investigate the impact of international migration on unemployment in 2005- 
06 and 2011-12 years. The analysis results indicate that the increase in international migration led to a decrease in unemployment rates in the short run. According to Moreno-Galbis and Tritah's (2016) estimates that obtained using data on immigrants in 13 European countries in the 1998-2004 period, show that the employment rate of indigene in sectors where more immigrants get a job increased. Finally, Georgiana Noja and Son (2016), performed an analysis in 8 European countries for the period 2000-2014. According to results, international migration has a negative effect on employment rates in the short term. This effect becomes more dominant in the long term.

There are also studies investigating the impact of international migration on labour markets on a country basis in Europe. Firstly, there are some studies examining the effects of international migration in Germany. Pischke and Velling (1997) performed an analysis at the regional level and between the period 1985-1989. According to the results, international migration has no direct impact on employment. Bonin (2005) stated that international migration does not affect unemployment in the 1975-1997 period. Glitz (2012) expressed that Germany received approximately 2.8 million immigrants during the 15 years after the fall of the Berlin Wall. Therefore, it is comprehensively analysed that the effect of international migration on employment markets in the 1996-2001 period. There are also some studies investigating the effects of international migration on employment in England. Firstly, Dustmann et al. (2005), in his analysis include between the period 1988-2000, express that international migration has a negative effect on the employment of workers with secondary education in the UK economy. However, there is no effect on the rest of the employment markets. Secondly, Lucchino et al. (2012) investigate the relationship between international migration and unemployment in the United Kingdom between 2002-2010. The analysis results show that there is no relationship between international migration and unemployment. Edo (2015) performed an analysis in the French economy for the period 1990-2002. It is used micro-level data to reveal the impact of international migration on local employment in the analysis. Accordingly, it is stated that international migration has negative effects on employment. On the other hand, Carrasco et al. (2008) investigate that the impact of international migration on employment rates in the period 1993-1999 in Spain, which is exposed to a heavy influx of South American and African migrants. The estimation results indicate that there is no negative effect on employment rates. Strielkowski and Troshchenkov (2013) analysed the impact of migration on unemployment rates in Denmark. It is used that cross-section data for the period 2007-08-09 in the analysis. According to results, international migration that is nonWestern origin does not have a significant effect on unemployment rates.

\section{Empirical Model, Methodology and Data Set}

In the study, the impact of international migration on unemployment rates in the European countries is analysed. This region has received quite a lot of international migration since the 2000s. It is included 27 countries in the analyses. These countries are as follows, Belgium, Czech, Denmark, Germany, Estonia, Ireland, Greece, Spain, France, Croatia, Italy, Southern Cyprus, Lithuania, Latvia, Luxembourg, Hungary, Netherlands, Austria, Poland, Portugal, Slovenia, Slovakia, Finland, Sweden, UK, Norway, and Switzerland. The analysis includes the period of 2000-2017.

\section{Empirical Model and Methodology}

Panel data analysis is chosen as the empirical method. Panel data analysis enables to analyse with a data set that includes both cross-section and time-series data (Baltagi, 2005). Since the data of the study are both cross-section and time-series form, it is appropriate to use the panel data analysis method in the analysis. Panel data analysis is very useful due to its advantages. Firstly, the cross-section and time-series data form will provide a large number of observation values. Thus, the estimates will be more reliable. Secondly, independent variables differ in cross-section and dimension. This reduces the possibility of multicollinearity problems.

$$
\text { LNUNEMPLOYMENT } i t=\beta_{0}+\beta_{1} \Delta L N M I G R A T I O N_{i t}+\beta_{2} \Delta L N X_{i t}+u_{i t}
$$

$$
u_{i t}=\mu_{i}+v_{i t}
$$

Equation (1) show the econometric model used in the estimation of panel regression. In equation (1), $\mathrm{i}$ denotes countries and $\mathrm{t}$ is time. The dependent variable (LNUNEMPLOYMENT) shows the unemployment rate. The main independent variable of the analysis ( $\triangle$ LNMIGRATION) indicates the 
international migration to the countries. $\Delta \mathrm{X}$ is the vector of other independent variables that have an effect on the unemployment rate. These variables are GDP, public expenditure, education expenditure, and wage. In equation (2) $u_{i t}$ shows the unobservable individual effect, $v_{i t}$ is the error terms. $\mu_{i}$ describes individual effects that do not change time-dependent and are not included in regression (Baltagi, 2005, p. 11). Equation (1) is estimated by pooled regression, fixed, or random-effects approach. Hausman, Breusch-Pagan LM test, and F test are performed to determine which of these approaches will be used. Finally, diagnostic tests such as multicollinearity, autocorrelation, heteroscedasticity are performed. Robust estimators can be used based on these statistical problems.

\section{Data Set}

The estimation is performed with annual frequency data. Table 1 shows the definitions of variables in the model.

The dependent variable is LNUNEMPLOYMENT that refers unemployment rate in the total population. As the basic independent variable of the model is $\triangle$ LNMIGRATION that shows the number of immigrants from the country of origin to the countries. Theoretically, neo-classical theories argue that migration is caused by problems such as high unemployment and/or low wages in the origin of the country, and so, they infer that international migration will directly affect labour markets, and unemployment will increase. Piore (1986) concludes that there will be a labour-capital exchange between the receiving and originating countries in the labour market and that international migration will not directly affect unemployment, given that immigrants are concentrated in the unstable and unskilled secondary sector in the labour market3. Accordingly, the estimation results are expected to show that immigration has no effect on unemployment or increases unemployment in the receiving country. The first control variable added to the model is $\triangle$ LNGDP that reflects the countries real income. In the economic theory, the countries income level is one of the most important variables that affect the unemployment rate. The relationship between real income and unemployment is mostly based on Okun (1962). Okun Law argues that there is an inverse relationship between real growth and unemployment rates. However, It is theoretically determined the effect of economic growth on employment by factors that the flexibility of wages, the economy's labour-intensive or capital-intensive growth, etc. Because of this, the effect of economic growth on employment varies among countries, and there are some situations where economic growth does not affect employment (Yllmaz, 2005, p. 65-66). Accordingly, the coefficient of the $\triangle$ LNGDP is expected to be negative. The third independent variable in the model is public expenditure ( $\triangle$ LNPUBLICEXP). This variable is added to the model as the share of public expenditures in total income. The classical economic view argues that the economy will be at full employment level as long as without state interference in the economy. The Keynesian view, on the other hand, proposes to increase the public expenditure at the underemployment equilibrium in the 1929 crisis, and so reducing the unemployment rates. In the following periods, significant ideas emerged about these characteristics of the public sector, which are described as problematic or problem solving on unemployment. The opinion that the growth in the public sector will cause unemployment focuses on two issues. The first is that the government has an exclusionary effect on private investments by misallocation. Second, the increase in budget deficits is destabilizing macroeconomic stability in the long run. The other opinion argues that expansionary economic policies in especially economic crisis will take a turn the economy from underemployment (Durkaya, \& Ceylan, 2016, p. 27). The coefficient of $\Delta$ LNPUBLICEXP is expected to be positive or negative based on these two theoretical arguments.

The other independent variable is education expenditures ( $\triangle$ LNEDUCATION) that is referred share of public education expenditures in GDP. The relationship between education and unemployment is explained by the effect of human capital level on productivity. Accordingly, firms are reluctant to lay off their highly productive employees. In other words, the unemployment rate decreases as firms will want to employ labour with high productivity (Núñez, \& Livanos, 2010, p. 477). However, it can be stated that the unemployment rates among people with high education level have been quite high in recent years. Teichler (1999) emphasizes the imbalances in the labour markets as the cause of the unemployment that occurs despite the increase in education level. To put it more clearly, the mismatch between labour demand and labour supply leads to an increase in unemployment rates. According to these two arguments,

\footnotetext{
${ }^{3}$ Divided Labour Market and Cumulative Causality Theories support this argument.
} 
the coefficient of the $\triangle$ LNEDUCATION variable is expected to be positive or negative. The last

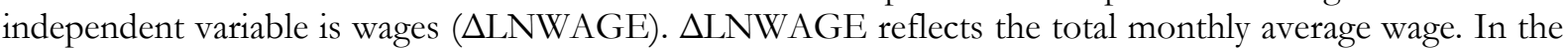
labour market where perfect competition market conditions prevail, the wage rises increase the unemployment rates. However, efficiency wage theories provide explanations as to why firms see it more profitable to pay wages higher than the equilibrium wage level. These theories put emphasis on consideration such as improving the productivity of the workers; not to lose its qualified workers to competitors; avoiding costs incurred during workers change (education, etc.); preventing workers from slacking off; avoiding the union (Adaş, 2002). Therefore, the efficiency wage hypothesis provides an essential theoretical background for labour markets where employment remained stable or increased despite wage rises. In addition, the bargaining hypothesis states that the bargaining power of the unions is high, especially in periods when unemployment rates are low, and therefore, the possibility of realization of the wage increase demands of the unions is more likely in these periods. In this case, the effect of wages on unemployment rates cannot be explained with the classical labour market theory (Pazarlıoglu, \& Çevik, 2007, p. 6). Accordingly, the coefficient of the $\Delta$ LNWAGE is expected to be positive or negative.

Table 1. Variables' Definitions

\begin{tabular}{cccc}
\hline & Explanation & Coefficient Expectation & Data Source \\
\hline LNUNEMPLOYMENT & Unemployment Rate (\%) & The Dependent Variable & Eurostat \\
LNMIGRATION & Number of Immigrants & $+/$ Neutral & Eurostat \\
LNGDP & GDP (2010, million euro) & - & Eurostat \\
LNPUBLICEXP & Public Expenditure (\% of GDP) & $+/-$ & Eurostat \\
LNEDUCATION & Education Expenditure (\% of GDP) & $+/-$ & Eurostat \\
LNWAGE & Average Monthly Wage (euro) & $+/-$ & UNECE \\
\hline
\end{tabular}

Table 2 show descriptive statistics for variables. Accordingly, the model is estimated with an average of 500 observations. While the average LNUNEMPLOYMENT is 1.72, the lowest and highest unemployment rates are 0.33 and 3 in the sample. The means of LNPUBLICEXP and LNEDUCATION are 3.79 and 1.64. Lastly, the means of LNMIGRATION, LNGDP, and LNWAGE is calculated as 10.8, 12.1 and 7.71 , respectively.

Table 2. Descriptive Statistics

\begin{tabular}{cccccc}
\hline Variable & $\boldsymbol{N}$ & Mean & Sd. & Min. & Max. \\
\hline LNUNEMPLOYMENT & 513 & 1.72 & 0.49 & 0.33 & 3.00 \\
LNMIGRATION & 501 & 10.8 & 1.53 & 3.55 & 14.2 \\
LNGDP & 513 & 12.1 & 1.48 & 9.26 & 14.9 \\
LNPUBLICEXP & 512 & 3.79 & 0.15 & 3.23 & 4.17 \\
LNEDUCATION & 512 & 1.64 & 0.17 & 1.16 & 1.97 \\
LNWAGE & 496 & 7.71 & 0.74 & 5.54 & 9.0 \\
\hline
\end{tabular}

\section{Empirical Results}

Performing analysis with non-stationary series causes spurious regression. Therefore, in order for the analyses to give significant and reliable results economically and statistically, the series must be stationary. Before the model is estimated, the stationarity of the series to be used in estimations is tested. The crosssection dependency problem of the series is taken into account in the selection of the unit root test in which the stationarity of the series is investigated. The cross-sectional dependence is a significant problem in which all units in the same cross-section are correlated, in the panel data analysis. If there is a crosssectional dependency problem in the series, the second-generation unit root test is used ${ }^{4}$. Table 3 presents the results of Pesaran CD, in which the cross-sectional dependency problem is investigated, and the CADF (Cross Sectionally Augmented Dickey-Fuller) and CIPS (Cross-Sectionally Augmented IPS) unit root test, in which the stationary of series is tested. There are many tests investigating cross-sectional dependency such as Breusch-Pagan LM, Pesaran scaled LM, Bias-corrected scaled LM and Pesaran CD test. Pesaran CD test gives efficient results when the panel data set is N $>$ T. According to the Pesaran CD test results, all variables have cross-section dependency problem. In this direction, the CADF unit root

\footnotetext{
${ }^{4}$ Panel unit root tests are categorized in two parts according to the cross-sectional dependency problem in the series. If there is no cross-section dependency problem, it is used the first-generation unit root tests such as Levin and Lin; Im, Pesaran and Shin; Harris and Tzavalis. If there is a cross-sectional dependency problem, second-generation unit root tests such as the CrossSectionally Augmented IPS (CIPS) and Cross- Sectionally Augmented Dickey-Fuller (CADF) should be preferred.
} 
test suggested by Pesaran (2007) and CIPS unit root test is used to detect stationary of series. CADF test results show that LNUNEMPLOYMENT is stationary at level; the other variables are stationary at the first difference. The series has been made stationary by taking the difference.

Table 3. Pesaran CD, CADF and CIPS Unit Root Test Results

\begin{tabular}{ccccccc}
\hline & \multicolumn{2}{c}{ Pesaran CD Test } & \multicolumn{2}{c}{ CADF Test } & \multicolumn{2}{c}{ CIPS Test } \\
\hline & Stat. & Prob. & Level & $\begin{array}{c}\text { First } \\
\text { Difference }\end{array}$ & Level & $\begin{array}{c}\text { First } \\
\text { Difference }\end{array}$ \\
\hline LNUNEMPLOYMENT & 19.51286 & 0.000 & $-2.040^{* *}$ & & $-2.664^{* * *}$ & $-3.588^{* * *}$ \\
LNMIGRATION & 19.58162 & 0.000 & -1.832 & $-2.783^{* * *}$ & -1.855 & $-2.727^{* * *}$ \\
LNGDP & 60.18394 & 0.000 & -1.891 & $-2.133^{* *}$ & -1.296 & $-4.346^{* * *}$ \\
LNPUBLICEXP & 27.52380 & 0.000 & -1.668 & $-2.492^{* * *}$ & -2.061 & $-4.022^{* * *}$ \\
LNEDUCATION & 19.04212 & 0.000 & -1.368 & $-2.814^{* * *}$ & -1.487 & $-3.090^{* * *}$ \\
LNWAGE & 72.41600 & 0.000 & $-2.291^{* * *}$ & $-2.747^{* * *}$ & -1.626 &
\end{tabular}

Table 4 shows the results of the diagnostic tests. Firstly, it is investigated whether the model to be estimated is suitable for the pooled regression model, fixed effect and random effect models. Firstly, the Hausman test performed. In this test, the null hypothesis is that there is no correlation between the unique errors and the regressors in the model and the alternative hypothesis is that there is a correlation between the unique errors and the regressors in the model. According to the Hausman test, the null hypothesis is rejected. Therefore, the fixed-effects model is preferred to the random-effects model. The null hypothesis is rejected in the F test. Accordingly, the fixed-effects model is preferred to the pooled regression model. As a result, the econometric model in equation (1) estimated by taking into account the fixed effects. Some tests have been performed to determine statistical problems in estimations. Pesaran $\mathrm{CD}$ and Friedman $\mathrm{R}$ test results indicate that there is cross-section dependency problem in estimations. According to the Modified Wald test, there is heteroskedasticity in the estimations of model. In the modified Bhargava Durbin-Watson and Baltagi-Wu LBI test, the statistical values are calculated as 0.46 and 0.68 , respectively. Since the statistical values are less than two, it has been decided that there is an autocorrelation problem in the estimations.

Table 4. Diagnostic Tests

\begin{tabular}{lcc}
\hline & Stat. & Prob. \\
\hline Hausman Test & 22.44 & 0.0004 \\
Breusch-Pagan LM Test & 1111.38 & 0.0000 \\
F Test & 33.58 & 0.0000 \\
Modified Wald Test for Groupwise Heteroskedasticity & 3820.05 & 0.0000 \\
Pesaran Cross-Section Dependency Test & 13.844 & 0.0000 \\
Friedman Cross-Section Dependency Test & 42.556 & 0.0215 \\
Modified Bhargava Durbin-Watson Test & 0.4682 & \\
Baltagi-Wu LBI Test & 0.6851 & \\
\hline
\end{tabular}

The estimations have been re-performed using robust estimators to eliminate the statistical problems. Accordingly, Driscoll and Kraay estimator is used. Table 5 show the panel regression estimations. According to the estimation results, the impact of international migration on unemployment is not statistically significant. GDP has the most prominent effect on the unemployment rate. Accordingly, increases in GDP reduce unemployment rates. In addition, increases in public or education expenditures and wage rise also reduce unemployment rates.

Table 5. Regression Results

\begin{tabular}{|c|c|c|c|c|}
\hline Variable & Coefficient & Sd. Error & Drisc/Kraay Sd. Error & Prob. \\
\hline$\triangle \mathrm{LLNMIGRATION}$ & 0.0095 & 0.0547 & 0.0897 & 0.916 \\
\hline$\Delta \mathrm{LNGDP}$ & -3.3321 & 0.5455 & 0.8758 & 0.001 \\
\hline$\triangle \mathrm{LNEDUCATION}$ & -0.7557 & 0.2526 & 0.4300 & 0.091 \\
\hline$\triangle \mathrm{LNWAGE}$ & -0.9064 & 0.1517 & 0.2945 & 0.005 \\
\hline Constant & 1.83658 & 0.0166 & 0.0344 & 0.000 \\
\hline
\end{tabular}


Estimations show that international migration does not have a statistically significant effect on unemployment rates in 27 European countries. This result is consistent with the Divided Labour Market and Cumulative Causality Theories. In addition, the estimations are similar to results of papers such as Pisckhe, \& Velling (1997), Bonin (2005), Longhi et al. (2010).

\section{Conclusion}

The aim of the study is to investigate empirically the effect of international migration on unemployment rates in European countries. The analysis method of the study is panel regression. The dependent variable in the econometric model is the unemployment rate. Independent variables are migration, which is the main independent variable, GDP, public expenditure, education expenditure and wages. The data set include between the period of 2000-2017 in 27 European countries. Estimation results show that international migration does not have a statistically significant effect on unemployment rates. On the other hand, the increase in GDP, public expenditures, education expenditures and wage rise reduce unemployment rates. In addition, the main determinant of unemployment rates is GDP. This result is consistent with the Divided Labour Market and Cumulative Causality Theories. In addition, the estimations are similar to results of papers such as Pisckhe and Velling (1997), Bonin (2005), Longhi et al. (2010).

As a result, this study has confirmed the situation of migrants already doing "immigrant work" in the labour market, which is predicted by migration theories, especially the dual labour market theory. As migrant workers turn (or are directed) into unstable and unskilled jobs, what kind of effect they have on unemployment rates is not easily distinguishable. As a matter of fact, the empirical estimations has confirmed this. This result can also be interpreted as the approach of the "potentially suspicious" towards immigrants is as subjective rhetoric, far from a scientific approach. Because, when an evaluation is made on the variables, it can be stated that the other variables such as GDP, public expenditures, education expenditures and the wage rises have a determining role on unemployment in contrast to the international migration. These variables are related to the country's own economic policies rather than immigrants or immigration mobility. Therefore, it can be expressed that unemployment in European countries is related to domestic economic variables rather than international migration. This result also points to the need for policy makers to act on data, not perceptions, in policies regarding immigrants. In this way, policy recommendations for the future of the relations between immigrants and the host society will be determined in a much more realistic and healthy way.

\section{Ethical Declaration}

In the writing process of the study titled "The Effect of International Migration on Unemployment: An Empirical Analysis on the European Countries" there were followed the scientific, ethical and the citation rules; was not made any falsification on the collected data and this study was not sent to any other academic media for evaluation. Since the data set is used in this article, ethics committee approval is not required.

\section{References}

Abadan-Unat, N. (2017). Bitmeyen göcs konuk işcilikten ulus-ötesi yurttaşlğ̆a. İsanbul: Bilgi Üniversitesi Yayınları.

Adaş, C. G. (2002). Etkin ücret hipotezi, işsizlik ve ücret rijidliği. İktisat Fakültesi Mecmuasi, 52(1), 103-156.

Angrist, J., \& Kugler, A. (2001). Protective or counter-productive? European labor market institutions and the effect of immigrants on EU natives. NBER Working Paper, No: 8660. https://doi.org/10.3386/w8660

Baltagi, B. H. (2005). Econometric analysis of panel data. John Wiley\&Sons, Ltd.

Bijak, Jakub (2006). Forecasting international migration: Selected theories, models and methods. CEFMR Working Paper.

Bonin, H. (2005). Wage and employment effects of immigration to Germany: Evidence from a skill group approach. IZA Discussion Paper, No: 1875.

Boubtane, E., Coulibaly, D., \& Rault, C. (2013). Immigration, growth, and unemployment: Panel VAR evidence from OECD Countries. Labour, 27(4), 399-420. https://doi.org/10.1111/labr.12017

Breunig, R., Deutscher, N., \& To, H. T. (2017). The relationship between immigration to Australia and the labour market outcomes of Australian-Born workers. Economic Record, 93(301), 255-276. https://doi.org/10.1111/1475-4932.12328

Carrasco, R., Jimeno, J. F., \& Ortega, A. C. (2008). The effect of immigration on the labor market performance of native-born workers: Some evidence for Spain. Journal of Population Economics, 21(3), 627-648. https://doi.org/10.1007/s00148-006-0112-9

Castles, S., \& Miller, M. J. (1993). The age of migration: international population movements in the modern world. Macmillan.

Castles, S., \& Miller, M. J. (2008). Göcler çă̆̊: Modern Dünyada uluslararası gọ̈s hareketleri. (Çev. Bal, B. U., \& Akbulut, İ.). İstanbul Bilgi Üniversitesi Yayınları. 
Cohen-Goldner, S., \& Paserman, M. D. (2004). The dynamic impact of immigration on natives' labor market outcomes: Evidence from Israel. IZA Discussion Papers, No: 1315.

Damette, O., \& Fromentin, V. (2013). Migration and labour markets in OECD countries: A panel cointegration approach. Applied Economics, 45(16), 2295-2304. https://doi.org/10.1080/00036846.2012.661400

Docquier, F., Ozden, C.., \& Peri, G. (2016). The labour market effects of immigration and emigration in OECD countries. IZA Discussion Paper, No: 6258. https://doi.org/10.1142/9781

Douglas, M., Arango, J., Hugo, G., Kouaouci, A., Pellegrino, A., \& Taylor, J. E. (2014). Uluslararası göç kuramlarının bir değerlendirmesi. (Çev. Dedeoğlu, S., Oskay, B., Özbek, Ç., Sirkeci, İ., \& Yüceşahin, M.). Göç Dergisi, 1(1), 11 46.

Durkaya, M., \& Ceylan, S. (2016). İşsizliğin azaltılmasında kamu kesimi büyüklüğünün rolü. Finans Politik \& Ekonomik Yorumlar, 53(615), 23-40.

Dustmann, C., Fabbri, F., \& Preston, I. (2005). The impact of immigration on the British labour market. Economic Journal, 115(507), F324-F341. https://doi.org/10.1111/j.1468-0297.2005.01038.x

Edo, A. (2015). The impact of immigration on native wages and employment. B.E. Journal of Economic Analysis and Policy, 15(3), 1151-1196. https://doi.org/10.1515/bejeap-2014-0075

Eurostat. (2020). Retrieved from: https://ec.europa.eu/eurostat/data/database. (Accesed Date: 02.07.2020).

Georgiana Noja, G., \& Son, L. (2016). Challenges of international migration in a globalized world: implications for Europe. International Journal of Innovation and Economic Development, 2(3), 7-17. https://doi.org/10.18775/ijied.1849-7551-7020.2015.23.2001

Glitz, A. (2012). The labor market impact of immigration: A quasi-experiment exploiting immigrant location rules in Germany. Journal of Labor Economics, 30(1), 175-213.

Güllüpınar, F. (2012). Göç olgusunun ekonomi-politiği ve uluslararası göç kuramları üzerine bir değerlendirme. Yalova Sosyal Bilimler Dergisi, 2(4), 53-85.

Gündoğmuş, B. (2018). Göç, din ve siyaset Avrupa'da milli görüs. Bilsam Yayıncılık.

Heywood, A. (2013). Küresel siyaset. Liberte Yayınları.

IOM. (2020). World Migration Report 2020. Retrieved from: https://publications.iom.int/system/files/pdf/wmr_2020.pdf. (Accesed Date: 12.09.2020).

Islam, A. (2007). Immigration unemployment relationship: The evidence from Canada. Australian Economic Papers, 46(1), 52-66. https://doi.org/10.1111/j.1467-8454.2007.00305.x

Jean, S., \& Jiménez, M. (2011). The unemployment impact of immigration in OECD countries. European Journal of Political Economy, 27(2), 241-256. https://doi.org/10.1016/j.ejpoleco.2010.11.006

Latif, E. (2015). The relationship between immigration and unemployment: Panel data evidence from Canada. Economic Modelling, 50, 162-167. https://doi.org/10.1016/j.econmod.2015.06.013

Lee, E. S. (1966). A theory of migration. Demography, Population Association of America, 3(1), 47-57.

Lewis, W. A. (1954). Economic development with unlimited supplies of labour. The Manchester School of Economic and Social Studies, 22(2), 139-191.

Longhi, S., Nijkamp, P., \& Poot, J. (2006). The impact of immigration on the employment of natives in regional labour markets: $A$ meta-analysis. IZA Discussion Paper, No: 2044.

Longhi, S., Nijkamp, P., \& Poot, J. (2010). Joint impacts of immigration on wages and employment: Review and meta-analysis. Journal of Geographical Systems, 12, 355-387. https://doi.org/10.1007/s10109-010-0111-y

Lucchino, P., Rosazza-Bondibene, C., \& Portes, J. (2012). Examining the relationship between immigration and unemployment using national insurance number registration data. NIESR Discussion Paper, No: 386.

Maslow, A. H. (1943). A theory of human motivation. Psychological Review, 50(4), 370396. https://doi.org/10.1037/h0054346.

Meyer, J; Brian Rowan. (1977). Institutionalized organizations: Formal structure as myth and ceremony, American Journal of Sociology, 83 (2), 340-363.

Moreno-Galbis, E., \& Tritah, A. (2016). The effects of immigration in frictional labor markets: Theory and empirical evidence from EU countries. European Economic Review, 84, 76-98. https://doi.org/10.1016/j.euroecorev.2015.10.001

Núñez, I., \& Livanos, I. (2010). Higher education and unemployment in Europe: An analysis of the academic subject and national effects. Higher Education, 59(4), 475-487. https://doi.org/10.1007/s10734-009-9260-7

Okun, A. M. (1962). Potential GNP: Its measurement and significance. Cowles Foundation Paper.

Ortega, F., \& Peri, G. (2009). The causes and effects of international migrations: Evidence from OECD countries 1980-2005. NBER Working Paper Series, No: 14833.

Ortiz, J., Grimée, J., \& Prichard, T. (2015). Analyzing the impact of immigration on unemployment in European Union [Econometric Analysis Undergraduate Research Papers]. College of Liberal Arts - Ivan Allen College (IAC).

Ozcan, B. (2020). The relationship between immigration, labour market conditions and GDP: Evidence from the states of the USA. Global Business and Economics Review, 23(1). https://doi.org/10.1504/gber.2020.10029805

Pazarlıŏlu, V., \& Çevik, E. İ. (2007). Verimlilik, ücretler ve işsizlik oranları arasındaki ilişkinin analizi: Türkiye örneği. Yönetim ve Ekonomi, 14(2), 1-17.

Pesaran, M. H. (2007). A simple panel unit root test in the presence of cross-section dependence. Journal of Applied Econometrics, 22(2), 265-312. https://doi.org/10.1002/jae.951. 
Petersen, W. (1958). A general typology of migration. American Sociological Review, 23(3), 256-266.

Piore, M. J. (1986). The shifting grounds for immigration. The Annals of the American Academy of Political and Social Science, 485, 23-33.

Pischke, J. S., \& Velling, J. (1997). Employment effects of immigration to Germany: An analysis based on local labor markets. The Review of Economics and Statistics, 79(4), 594-604.

Ravenstein, E. G. (1885). The laws of migration. Journal of the Statistical Society of London, 48(2), 167-235.

Robinson, R. (2005). Beyond the state-bounded immigrant incorporation regime: Transnational migrant communities: Their potential contribution to Canada's leadership role and influence in a globalized world. The North-South Institute.

Stark, O., \& Bloom, D. E. (1985). The new economics of labor migration. The American Economic Review, 75(2), $173-$ 178.

Strielkowski, W., \& Troshchenkov, S. (2013). Economic impact of immigration in Canada. Актуальні Проблеми Економіки, 8(146), 443-450.

Teichler, U. (1999). Higher education policy and the world of work: Changing conditions and challenges. Higher Education Policy, 12, 285-312.

UNECE. (2020). Retrieved from: https://w3.unece.org. (Accesed Date: 02.07.2020).

Yılmaz, Ö. G. (2005). Türkiye ekonomisinde büyüme ile işsizlik oranları arasındaki nedensellik ilişkisi. Ekonometri ve Istatistik e-Dergisi, 2, 63-76.

\section{TÜRKÇE GENİ̧̧ ÖZET}

Göç olgusu, 20. ve 21.yy’a damgasını vuran önemli bir nitelik arz etmektedir. Castles ve Miller’in (1993) ifadesiyle "göçler çağı" olarak nitelendirilen bu dönemde, göçün niçin ve nasıl gerçekleştiği hususunu ele almak, göçün diğer değişkenlerle ilişki boyutunu ortaya koymak sosyal bilimciler için kaçınılmaz bir sorumluluk ve zorunluluk halini almışır. Nitekim ekonomik ve siyasal gelişmeler bağlamında göçün güncellenerek varllğını sürdürmesi bir yana; görece daha fazla ülkeyi etkilemesi bakımından göçün küreselleşmesi, uluslararası göç hareketliliğinin artışından ötürü göçün hızlanması, göç ve göçmen örüntülerinin görece karmaşıklaşması nedeniyle göçün farklılaşması, ilk dönemlere oranla göçün kadınsallaşması ve hükümetler arası ilişkiler ve artan güvenlik politikaları nedeniyle göçün giderek siyasallaşması söz konusudur (Castles vd., 2008, s. 12-14). Göç olgusunun bu boyutları sayısal verilere de yansımaktadır. Uluslararası Göç Örgütü (IOM) verilerine göre, 1970 yllında yaklaşık 85 milyon olan uluslararası göçmen sayısı, 2019 yılı sonu itibariyle dünya nüfusunun \%3,5'ine tekabül edecek şekilde 250 milyona ulaşırken, 2020 y1lı tahminleri ise 275 milyon dolaylarında seyretmektedir (IOM, 2020). Göçün bu denli yaygınlaşması kuşkusuz etki alanını da artırmaktadır.

Özünde mekânsal hareketliliği vurgulayan göç olgusu, bünyesinde barındırdığı geniş kapsamıyla uzun bir sürece atıf yapmaktadır. Nitekim ülke içine ya da dışına dönük olacak şekilde A noktasından herhangi bir sebeple hareket eden birey ya da grupların B noktasına varışı, süreci bitirmemekte, tam aksine sosyal, siyasi, ekonomik alanlarda süreklilik arz eden değişim ve dönüşümleri tetiklemektedir. Bu uzun soluklu süreci açıklamaya dönük teorik çerçevenin sürekli olarak güncellenmesinin kaynağında da bu gerçeklik yatmaktadır. Çalışmada ele alınan uluslararası göçün 20.ve 21.yüzyılda izlediği seyir takip edildiğinde bu durum net bir şekilde görülebilmektedir. Özellikle İkinci Dünya Savaşı sonrasında gözlemlenen yoğun uluslararası göç hareketliliğinin temel motivasyonu işgücü piyasaları olurken, 2000’li yıllarda iç çatışma, işgal ve savaşların göçe neden olduğu bu nedenle de güvenlik merkezli teorik yaklaşımların gündeme getirildiği görülmektedir. Çalışmanın konusu göç ile işgücü piyasaları arasındaki ilişkiye odaklandığı için yoğunlaşılması gereken teorik çerçeve ekonomik yaklaşım merkezli olmaktadır. Bu anlamda öne çıkan ekonomik teoriler arasında; neoklasik makro/mikro teori, göçün yeni ekonomisi, itme-çekme teorisi, kümülatif nedensellik, dünya sistemleri teorisi, kurumsal kuram ve ikili emek piyasası teorisi yer almaktadır.

Peki, 2020 yllı itibariyle göçün işgücü piyasalarıyla arasındaki ilişki düzeyini nasıl değerlendirmek gerekiyor? Geçmiş dönemlerle kıyaslandığında herhangi bir değişim söz konusu mudur? Bu ve benzeri soruların yanıtının arandığı çalışma aynı zamanda, göç alan ülkede çoğu zaman "potansiyel şüpheli” olarak görülen göçmenlerin işgücü piyasasında en zayıf halka olmalarına koşut olarak gelişen "ekonomik krizlerin faturasını göçmenlere ödetme" yaklaşımının doğruluk payının analiz edilmesine de firsat sunabilecektir. $\mathrm{Bu}$ kapsamda ele alınan çalışmada, ampirik araştırma tekniği kullanılarak 2000-2017 yılları arasında kayda alınan resmi istatistiksel verilerden yararlanılmıstır. Bu veriler üzerinden elde edilmek istenen sonuç ise, göçün işsizlik oranları üzerinde ne yönde bir etkide bulunduğu hususudur. Esasında, literatür taraması yapıldığında konu ile ilgili farklı sonuçlara ulaşan hatırı sayılır oranda araştırmaya ulaşılmaktadır. $\mathrm{Bu}$ araştırmayı özgün kılan faktör ise, çeşitli nedenlerle Ortadoğu ve Batı Asya'dan yoğun bir göçün olduğu bir döneme ilişkin verilerin kullanılarak görece güncel bir döneme dair sonuçlar elde edilmesidir. Bu kapsamda öncelikli olarak göç ile işgücü piyasaları arasındaki ilişkinin teorik çerçevesi, uluslararası göçü açıklamaya 
yönelik ekonomik temelli teoriler kullanılarak açıklanmakta ve konu ile ilgili geniş bir literatür taraması yapılmaktadır. Ardından, 27 Avrupa ülkesini içeren veriler kullanılarak panel regresyon yöntemiyle analiz gerçekleştirilmektedir. Son olarak analiz sonrası elde edilen sonuçlar paylaşılarak yorumlanmaktadır.

Çalışmada, Avrupa'da uluslararası göçün işsizlik oranları üzerindeki etkisinin ampirik olarak araştırılması amaçlanmışır. Bu doğrultuda panel regresyon yöntemi kullanılmıştır. Çalışmanın bağımlı değişkeni işsizlik oranıdır. Ekonometrik model, temel bağımsız değişken olarak belirlenen göçün dışında, GSYIH, kamu harcamaları, eğitim harcamaları ve ücretlerden oluşmaktadır. Çalışmanın örneklemi 27 Avrupa ülkesinde, 2000-2017 dönemini içermektedir. Tahmin sonuçları, göçün işsizlik oranları üzerinde istatistiksel açıdan anlamlı bir etkisi olmadığını göstermiştir. Diğer değişkenlerden GSYİH, kamu harcamaları, eğitim harcamaları ve ücretlerdeki artışlar işsizlik oranlarını düşürücü bir etki oluşturmaktadır. Bununla birlikte, katsayı büyüklüklerine bakıldığında işsizlik oranlarının temel belirleyicisinin GSYIH olduğu görülmektedir.

Sonuç olarak, gerçekleştirilen bu çalışma, ikili emek piyasası teorisi başta olmak üzere göç teorilerinin öngördüğ̈̈ göçmenlerin işgücü piyasasında zaten "göçmen işi” yapmaları durumunu teyit etmiştir. Göçmen işçiler istikrarsız ve vasıfsız işlere yöneldiğinden (ya da yönlendirildiğinden) onların işsizlik oranları üzerinde ne tür bir etkide bulundukları hususu kolaylıkla ayırt edilemez bir nitelik arz etmektedir. Nitekim araştırma sonucu da bunu doğrulamıştır. Bu sonuç aynı zamanda, göçmenlere dönük "potansiyel şüpheli”" yaklaşımının bilimsel yaklaşımdan uzak, sübjektif bir retorik olarak nitelendirilebileceği şeklinde de yorumlanabilmektedir. Zira değişkenler üzerinden bir değerlendirme yapildığında, diğer değişkenler olan GSYİH, kamu harcamaları, eğitim harcamaları ve ücretlerdeki artışı, göç değişkeninin aksine, işsizlik üzerinde belirleyici role sahip olduğunu göstermektedir. Bu değişkenler ise göçmenler ya da göç hareketliliğinden ziyade ilgili ülkenin ekonomik politikalarıla ilintili konular olmaktadır. Dolayısıyla, belirlenen ülkelerde işsizliğin göçten ziyade ülke içi ekonomik değişkenlerle ilişkili olduğu görülmüştür. Ortaya çıkan bu sonuç, politika yapıcıların göçmenler ile ilgili politikalarda algılar üzerinden değil veriler üzerinden hareket etmesinin gerekliliğine işaret etmektedir. Bu sayede göçmenler ile ev sahibi toplum arasındaki ilişkilerin geleceğine dönük politika önerileri çok daha gerçekçi ve sağlıklı bir şekilde tespit edilebilecektir. 